| Research Article / Araştırma Makalesi |

\title{
Examination of Teachers' Educational Information Network (EBA) Awareness In Terms of Some Variables
}

\section{Öğretmenlerin Eğitim Bilişim Ağı (EBA) Farkındalıklarının Bazı Değişkenler Açısından İncelenmesi}

\section{Umut Çardak ${ }^{1}$, Çetin Güler ${ }^{2}$}

\author{
Keywords \\ 1. EBA \\ 2. Educational \\ Informatics Network \\ 3. Awareness \\ 4. FATIH Project
}

Anahtar Kelimeler
1. EBA
2. Eğitim Bilişim Ağı
3. Farkındalık
4. FATiH Projesi

Received/Başvuru Tarihi 24.07.2020

Accepted / Kabul Tarihi 15.07.2021

\begin{abstract}
Purpose: In Turkey, in order to ensure equal opportunities in education and to ensure the integration of technology into education, the Action to Increase Opportunities and Improve Technology Project (FATIH) is carried out by the Ministry of National Education (MEB). One of the five basic pillars of this project is an online social education platform "The Educational Informatics Network (EBA) which is presented free to students, teachers and parents and provides access to tens of thousands of educational contents. Although there are many opportunities and benefits that EBA provides to all its stakeholders, it is not known whether teachers who are the planners and practitioners of the teaching process are aware of what they can do with this platform. With this research, it is aimed to reveal the EBA awareness of the teachers working in MEB schools and to examine these awareness in terms of many variables such as the province they work, branch, school type, the professional experience, the education level, the situation of receiving EBA education or not.

Design/Methodology/Approach: 244 teachers participated in the study. In order to collect data, a survey model was used., The data was collected through the Personal Data Form and the "Teacher EBA Awareness Scale " developed by the researchers.

Findings: As a result of descriptive analysis and comparisons, teachers' awareness of EBA was found to be "medium" and it was determined that this awareness differed from significantly according to the variables of branch, school type, number of technological tools owned, the ability of using technology, the status of training related to EBA, the status of being aware of the update made in EBA, number of EBA modules used and frequency of EBA use. However, it was determined that the status of having BTR teachers in schools were found to be unaffected by the variables.

Highlights: Since it is important to be informed about the platform in the use of the EBA, it is thought that new applications and features published on the platform should be announced to the teachers, measures should be taken to share them and more effective methods should be used for promotion.

Öz

Çalışmanın amacı: Türkiye'de eğitimde fırsat eşitliğinin sağlanması ve teknolojinin eğitime entegrasyonun sağlanması amacıyla Milli Eğitim Bakanlığı (MEB) tarafından Fırsatları Artırma ve Teknolojiyi İyileştirme Hareketi (FATiH) projesi yürütülmektedir. Bu projenin 5 temel ayağından biri olan "eğitsel e-içeriğin sağlanması ve yönetilmesi” ayağını; öğrenci, öğretmen ve velilerin ücretsiz erişimine sunulan ve on binlerce eğitim içeriğine ulaşılmasını sağlayan bir çevrimiçi sosyal eğitim platformu olan Eğitim Bilişim Ağı (EBA) oluşturmaktadır. EBA'nın tüm paydaşlarına sağladığı birçok imkan ve yarar bulunmasına rağmen öğretim süreçlerinin planlayıcı ve uygulayıcıları olan öğretmenlerin bu platform ile yapabileceklerinin farkında olup olmadığı bilinmemektedir. Bu araştırma ile; MEB'e bağlı okullarda görev yapan öğretmenlerin, EBA farkındalıklarının ortaya çıkarılması ve bu farkındalıklarının görev yaptıkları il, branş, okul türü, mesleki deneyim, öğrenim düzeyi, EBA eğitimi alıp almama durumu gibi birçok değişken açısından irdelenmesi amaçlanmıştır.

Materyal ve Yöntem: İki yüz kırk dört öğretmenin katıldığı ve nicel araştırma yöntemlerinden tarama modelinin kullanıldığ çalışmada veriler Kişisel Bilgi Formu ve araştırmacılar tarafından geliştirilen “Öğretmen EBA Farkındalık Ölçeği” ile toplanmıştır.
\end{abstract}

Bulgular: Yapılan betimsel analizler ve karşılaştırmalar sonucunda Öğretmenlerin EBA'ya ilişkin farkındalıkları "'”orta" düzeyde bulunmuş ve bu farkındalıkların branş, okul türü, sahip olunan teknolojik araç sayısı, teknoloji kullanma becerisi, EBA ile ilgili eğitim alma durumu, EBA'da yapılan güncellemeden haberdar olma durumu, kullanılan EBA modül sayısı ve EBA kullanım sıklığı değişkenlerine göre anlamlı farklılık gösterdiği ancak okullarda BTR öğretmeni bulunma durumu değişkeninden etkilenmediği tespit edilmiştir.

Önemli Vurgular: EBA kullanımında platform hakkında haberdar olmanın önemli olması nedeniyle platformda yayına alınan yeni uygulamaların ve özelliklerin öğretmenlere duyurulması, paylaşılması için tedbirler alınması ve tanıtım konusunda daha etkili yöntemler kullanılması gerektiği düşünülmektedir.

\footnotetext{
${ }^{1}$ Corresponding Author, Ministry of Education, Manisa, TURKEY; umutcrdk@gmail.com, https://orcid.org/ 0000-0003-4366-5179

${ }^{2}$ Van Yüzüncü Yıl University, Faculty of Education, Van, TURKEY; cetin@yyu.edu.tr, https://orcid.org/ 0000-0001-6118-9693
} 


\section{INTRODUCTION}

With the use of technology in education as in all areas of life, many concepts such as e-learning, blended learning, computer assisted learning and distance education emerged (Gökdaş \& Kayri, 2005; İşman, 2008; Yurdakul, 2016). These activities, the use and importance of which are increasing with each passing year, have gained even more importance after the Covid-19 cases (WHO, 2020), which emerged in December 2019 and caused millions of people to become ill and hundreds of thousands to die in the world (Telli \& Altun, 2020). As part of the measures taken in many countries in order to reduce deaths, reduce the rate of progression of the epidemic and gain time for treatment studies, face-to-face education in educational institutions was suspended for a while or schools were suspended (Dikmen \& Bahçeci, 2020). With this epidemic also seen in Turkey as of March 2020 (Ministry of Health, 2020), the Ministry of National Education (MEB) announced that face-to-face education will be suspended as of March 16, 2020, and distance education will be started as of March 23, 2020 (MEB, 2020a). ). The distance education process, on the other hand, is carried out through the Education Information Network (EBA), which was initiated with the FATIH Project which has the highest user number and most active distance education environment in Turkey as of today (MEB, 2020d).

The Movement to Increase Opportunities in Education and Improve Technology (FATIH) Project was initiated by the Ministry of National Education for the effective use of information technology tools in lessons, in a way to appeal to more sense organs in the learning-teaching process, in order to ensure equality of opportunity in education and training and to improve technology in schools (MEB, 2020c). It is stated that thanks to this project, it will be easier and faster for students to access the information they need (Kayaduman, Sırakaya, \& Seferoğlu, 2011). This project, which is based on a constructivist education approach, is based on five basic principles: "Accessibility", "Efficiency", "Equality", "Measurability" and "Quality" factors. Of the project:

It has five main components,

- In-service training of teachers

- Providing hardware and software infrastructure

- Effective use of Information Technologies (IT) in curricula

- Ensuring conscious, secure, manageable and measurable IT use, and

- Provision and management of educational e-content

The component of "Providing and managing educational e-content" is the EBA platform.

EBA, which was established by the Ministry of National Education and carried out by the General Directorate of Innovation and Education Technologies (YEĞiTEK), affiliated to the ministry; is an online social education platform that enables students, teachers and parents to access tens of thousands of educational content (EBA, 2020a). Many learning / teaching materials such as lectures, presentations, e-books, videos, simulations, animations, questions, exams, experiments are included in EBA. Through this platform, users can access the content at home, at school or wherever needed by using information technology tools. The potential to provide equal opportunities to students with different social and economic opportunities is also frequently expressed by the Ministry of National Education.

EBA, which has some deficiencies and flaws in some aspects previously from the eyes of teachers and students such as useless (Ekici, Arslan \& Tüzün, 2016), lack of functional help support (Erensayın \& Güler, 2017), lack of some content in the mobile version and slow loading (Kapıdere \& Çetinkaya, 2017), insufficient content and unsorted content (Alabay, 2015; Karaçorlu \& Aıcı, 2019), was introduced a new term on February 18, 2020, and a radical change was implemented in the platform.

In the promotion organized by the Ministry of National Education (2020b), the principle of "Justice of Opportunity in Education" was emphasized and it was stated that the content of the EBA (interactive school books, lecture videos, exams, applications, etc.) was updated, the user interface was renewed, giving it a modern and simple look and smart features. It is stated that by adding a content recommendation system according to the student's performance, it offers its users a personalized learning environment and personalized interface options. With the renewed EBA, students can make up for their shortcomings with the follow-up of their studies and personalized directions on the system, see their upcoming exams and events on their calendars, establish a social sharing area with their friends and make learning more fun by earning points and badges with the gamification system in the platform.

In terms of teachers, there are many activities-applications that can be made using EBA. The table below summarizes what teachers can do by using the modules in EBA. 
Table 1. What teachers can do using EBA modules (EBA, 2020b).

\begin{tabular}{|c|c|}
\hline Module Name & Teachers Can \\
\hline My Page & $\begin{array}{l}\text { - view the events in their personalised calendar } \\
\text { - make sharings (messaging, discussion, voting, activity) with the people in the school } \\
\text { · give feedback (comments, likes, etc.) on the shared message and } \\
\text { - follow the activity status of the students by following the works sent to the students }\end{array}$ \\
\hline Lessons & $\begin{array}{l}\cdot \text { access to all learning materials related to all grade levels and courses in EBA } \\
\text {-use the educational materials with the smart board mode and send these materials to the students as a } \\
\text { study when necessary }\end{array}$ \\
\hline Exams & $\begin{array}{l}\text { - access exercises and tests related to all classes, lessons and subject areas and send them to the } \\
\text { students }\end{array}$ \\
\hline Library & $\begin{array}{l}\text {-access thousands of educational and general cultural contents (e-books, e-journals, movies, videos, } \\
\text { audio files, etc.) belonging to different categories. }\end{array}$ \\
\hline Lists & - make personalized content arrangements according to teaching plans, \\
\hline Studies & $\begin{array}{l}\text { - see the work they sent to the students } \\
\text {. analyze past or ongoing works }\end{array}$ \\
\hline Reports & -monitor the reports of the studies they've sent both on a student-based and study-based basis \\
\hline Groups & $\begin{array}{l}\text { - create several groups with students and teachers } \\
\qquad \begin{array}{l}\cdot \text { join existing groups } \\
\cdot \text { add branches. }\end{array}\end{array}$ \\
\hline EBA Portfolio & $\begin{array}{l}\text { - follow students' academic achievements, social activities, projects, etc. they participate in and EBA } \\
\text { actions }\end{array}$ \\
\hline Files & - file and share as they wish to their personal $2 \mathrm{~GB}$ cloud storage \\
\hline Calendar & $\begin{array}{l}\text { - follow the activities and important days and weeks } \\
\text { - monitor the exam dates processed in the e-school }\end{array}$ \\
\hline Content Production & $\begin{array}{c}\text { produce original content } \\
\cdot \text { design learning steps and course flows using the content }\end{array}$ \\
\hline Question and Exam System & $\begin{array}{l}\text { - can access the questions and exams in EBA } \\
\cdot \text { add new questions and exams } \\
\cdot \text { send the exams as work } \\
\text { - take printouts of the exams when needed }\end{array}$ \\
\hline Professional Development & $\begin{array}{l}\text { · participate in in-service training such as various courses, seminars, etc. } \\
\cdot \text { join groups (21st Century Education World, Education Technologies, Classroom Management and } \\
\text { Guidance etc.) where they can share information and opinions with all their EBA using colleagues }\end{array}$ \\
\hline
\end{tabular}

Along with all the above-mentioned opportunities that EBA provides to students and teachers, there are findings in many studies on the use of this platform, indicating that it provides various benefits to students and teachers (Kılıç Koçak, 2019; Tüysüz \& Çümen, 2016). To students; Reinforcing, visualizing and concretizing the lesson for teachers with reinforcing the subjects, preparing for the exams, conducting interactive experiments, repeating the lessons and increasing academic success (Aydınözü, Sözcü, \& Akbaş, 2016; Ertem Akbaş, 2019; Tüysüz \& Çümen, 2016). , 2016), focusing students on the lesson (Karaçorlu \& Aıcı, 2019), facilitating classroom management (Kılıç Koçak, 2019), increasing motivation (Kuyubaşıoğlu \& Kılıç, 2019). Achieving these benefits depends primarily on the willingness of teachers, who are practitioners of the curriculum, to use technology in order to integrate technology in education (Fryer \& Bovee, 2016). In his research, Öz (2016) determined that cognitive awareness increases motivation and motivation increases success, so it is deduced that "awareness" is the basis of being motivated to a job. In a different study by Abdelrahman (2020); It has been revealed that there is a significant relationship between students' academic achievement and academic motivation, and that metacognitive awareness contributes to success in learning.

In a study investigating the effects of metacognitive awareness on students' participation in online classes (Tsai, Lin, Hong, \& Tai, 2018), it was concluded that increased metacognitive awareness was positively related to online learning participation. Accordingly, it can be said that being able to do a job effectively depends on motivation and therefore awareness. It can be argued that this situation is also valid for teachers who are planners and implementers of teaching processes.

In the workshop on "EBA usage" held on February 24, 2016 with teachers participating from all schools in Gürsu District of Bursa Province, the problem that EBA is not used frequently by teachers, even not recognized, was expressed as a result of the workshop (Özgümüş, 2018). Again, in many studies conducted in the literature, it is stated that teachers do not know EBA sufficiently (Aksoy, 2017; Kurtdede Fidan, Erbasan, \& Kolsuz, 2016; Saklan, 2017; Tutar, 2015) or do not use it at the expected level (Alabay, 2015; Güvendi, 2014; Karaçorlu \& Aıcl, 2019; Nakiboğlu and Gacanoğlu, 2019). Teachers' awareness of EBA can be discussed as one of the reasons why EBA is not used enough by teachers. Teachers' awareness of using the EBA platform will affect the efficiency and quality elements of the FATIH project, which are the two principles mentioned above. For this, it has been 
evaluated that it is important to determine the awareness of teachers about EBA, which was renewed and finalized in February 2020. In addition, Karaçorlu and AıC (2019) stated that examining teachers' awareness on the EBA platform will reveal the functioning of the FATIH Project.

When the literature is examined, many studies related to Fatih Project and EBA (Erensayın and Güler, 2019; Kalemkuş, 2016; Özgümüş, 2018; Saklan and Ünal, 2019; Yılmaz, 2013) etc. appears to be in some of these studies students (Bahçeci \& Burak, 2018; Coşkunserçe \& Becit İştürk, 2019; Tüysüz \& Çümen, 2016), teachers (Elçiçek, 2019; Kayaduman et al., 2011; Kurtdede Fidan, 2016; Şahin \& Erman, 2019) and the platform contents (Bertiz, 2017; Erensayın, 2018; Maden and Önal, 2018) are the focus. In studies focusing on teachers, variables such as attitude (Bayyiğit Teker, 2019), opinion (Saklan \& Ünal, 2018), competence (Kayaduman et al., 2011) and usage situations-frequency (Elçiçek, 2019; Nakiboğlu \& Gacanoğlu, 2019) have been discussed. . Coşkunserçe and Becit Incitürk (2019) carried out a study to increase students' awareness in their study. In this literature review, no study was found that addresses teacher EBA awareness. Determining the awareness of teachers, whose importance is emphasized above, may be important in terms of filling this gap.

Determining the EBA awareness of teachers and revealing how these awarenesses are affected by variables such as teachers' professional experience, education level, school type, branch, whether there is an Information Technologies Counselor in schools; it is anticipated that it will be important in terms of contributing to the authorities related to FATiH Project-EBA and the General Directorate of Teacher Training and Development of the Ministry and being a source for further research.

With this research; It is aimed to reveal the EBA awareness of the teachers working in the schools affiliated to the Ministry of National Education and to examine this awareness in terms of many variables such as the province, branch, school type, professional experience, education level, whether or not they have received EBA education. For this purpose, the problem sentence of the research was expressed as "What is the level of EBA awareness of the teachers" and the sub-problems of the study were determined as follows.

1- Does EBA awareness of teachers differ according to branches?

2- Does EBA awareness of teachers differ according to the type of school they work in?

3- Does the number of technological tools owned by the teachers have a significant effect on their EBA awareness?

4- Do teachers' technology use skills affect their EBA awareness?

5- Does the presence of Information Technologies Counselor (ITC) Teacher in schools change the EBA awareness of teachers?

6- Do teachers' awareness of EBA change according to their EBA education?

7- Does teachers' awareness of the latest updates in EBA significantly affect their awareness of EBA?

8- Does EBA awareness of teachers vary according to the number of EBA modules they use?

9- What is the relationship between teachers' EBA usage frequency and their awareness?

10- Which modules do teachers with EBA experience use mostly?

\section{METHOD/MATERIALS}

A descriptive survey model was used in this study, which aimed to reveal the awareness of teachers about EBA.

\section{Working Group}

A total of 244 teachers, 111 women (46\%) and 133 men (54\%), working in public/private schools affiliated to the Ministry of National Education in the 2019-2020 academic year from 22 different provinces, mostly from Van, participated in the working group.

The distribution of the participants according to some demographic information such as branch, school type, education level is presented in the table below.

Table 2. Distribution of the participants according to some demographic information

\begin{tabular}{|c|c|c|c|}
\hline Demographic Characteristics & & $\mathrm{N}$ & $\%$ \\
\hline \multirow[t]{4}{*}{ School Type } & Primary and Preschool & 77 & 32 \\
\hline & Secondary School & 112 & 46 \\
\hline & High School and Special Education & 55 & 22 \\
\hline & TOTAL & 244 & 100 \\
\hline \multirow[t]{4}{*}{ Branch } & Classroom Teaching & 56 & 23 \\
\hline & Technology Branches (Information Technology, Technology Design) & 35 & 14 \\
\hline & $\begin{array}{c}\text { Verbal Branches (Geography, History, Social Science, Turkish Language and Literature } \\
\text { etc.) }\end{array}$ & 38 & 16 \\
\hline & $\begin{array}{c}\text { Numerical Branches (Primary School Mathematics, Mathematics, Science, Physics, } \\
\text { etc.) }\end{array}$ & 35 & 14 \\
\hline
\end{tabular}

| Kastamonu Education Journal, 2021, Vol. 29, No. 5| 


\begin{tabular}{|c|c|c|c|}
\hline & Language Branches (English, Turkish) & 28 & 12 \\
\hline & Branches Requiring Special Talent (Physical education, music, visual arts, etc.) & 22 & 9 \\
\hline & $\begin{array}{c}\text { Developmental Branches (Guidance, special education, etc.) } \\
\text { TOTAL }\end{array}$ & $\begin{array}{c}30 \\
244\end{array}$ & $\begin{array}{c}12 \\
100\end{array}$ \\
\hline \multirow[t]{3}{*}{ Professional Experience } & $0-5$ Years & 97 & 40 \\
\hline & 6-10 Years & 100 & 41 \\
\hline & $\begin{array}{l}11 \text { Years and Over } \\
\text { TOTAL }\end{array}$ & $\begin{array}{c}47 \\
244\end{array}$ & $\begin{array}{c}19 \\
100\end{array}$ \\
\hline \multirow[t]{3}{*}{ Education Level } & Undergraduate & 214 & 88 \\
\hline & Postgraduate & 30 & 12 \\
\hline & TOTAL & 244 & 100 \\
\hline
\end{tabular}

As can be seen in Table 2, secondary school teachers (46\%) participated in the research the most among the school types collected in three groups. This was followed by primary and pre-school (32\%) teachers, and high school and special education (22\%) teachers, respectively. Since there were participation from 22 different branches in total, the branches within the same field were grouped in order to carry out the analysis processes more efficiently, and it was seen that the class teachers who were not included in any group (23\%) had the highest participation. This is followed respectively by verbal branches consisting of geography, history, etc., teachers (16\%), technology branches consisting of information technologies and technology design teachers (14\%), numeric branches consisting of mathematics, physics, biology, etc. teachers (14\%), developmental branches consisting of guidence, special education teachers (12\%), language branches consisting of English and Turkish teachers (12\%), and the branches that require special talents consisting of physical education, music, visual arts etc. teachers. When the professional experience of the teachers is examined, it is seen that the highest participation is from the teachers with 6-10 years (41\%) experience. This is followed by teachers with $0-5$ years of experience (40\%) and teachers with 11 years or more (19\%) experience. While the majority of the participants consist of undergraduate (88\%) graduate teachers, a partial portion consists of postgraduate teachers (12\%).

\section{Data Collection Tools}

In the study; Two data collection tools were used, the first being the "Personal Information Form" and the other being the "Teacher EBA Awareness Scale". Personal Information Form is a 13-item data collection tool in which general information such as the province, branch, and seniority year of the teachers are filled. The Teacher EBA Awareness Scale is a scale developed by researchers as a 5-point Likert type, which consists of 56 items in total and includes the options "(1) Disagree","(2) Partially Disagree", "(3) Undecided", " (4) Partially Agree", "(5) Agree".

In the development process of the Teacher EBA Awareness Scale; First of all, a literature review was conducted by an Information Technologies and Education (CEIT) Lecturer who is an expert in the field and an Information Technologies Teacher / CEIT Master's student, the skills under the "Help" section on the EBA web page were examined, and all the modules and functions in the EBA teacher section were analyzed and a scale item pool was created with 81 items under a total of 15 titles consisting of 14 modules and membership titles. Opinions were received from a Turkish Language and Literature teacher in order to ensure the linguistic validity of the created scale pool, and from four Information Technologies teachers and two academicians working in the field of CEIT in order to increase the content validity. Finally, the scale was piloted and construct validity (exploratory factor analysis) and reliability analyzes were applied with the IBM SPSS 22 package program.

The suitability of the data obtained as a result of the pilot application for factor analysis was examined by the Kaiser-MayerOlkin (KMO) coefficient and the Barlett sphericity test. When the results were examined, it was seen that the KMO value was 0.958 , and the Bartlett test was calculated as $\chi 2=19541,629, s d=2278, p=.000$. According to these results, it was decided that the scale was suitable for factor analysis (Büyüköztürk, 2018). As a result of the factor analysis, items with factor loading values below 0.30 and items with similar load values in more than one factor $(K=25)$ were removed from the measurement tool and the remaining 56 items of the measurement tool were analyzed again.

When the item load values from the outputs given as a result of the factor analysis and the "Total Explained Variance" table are examined; It was seen that the $\mathrm{K}=56$ items included in the analysis were gathered under two factors with an eigenvalue greater than 2 . The variance explained by these two factors regarding the scale is $64,401 \%$. Accordingly, it was seen that these two factors together explained most of the variance of the scale. After factor rotation using the Varimax method, it was determined that the first factor consisted of 35 items and the second factor consisted of 21 items.

Table 3. Some information on the factors resulting from the analysis

\begin{tabular}{|c|c|c|c|}
\hline Factor & Number of Article & Articles Related to EBA Modules & Articles' Load Value Range in Factor \\
\hline Factor 1 & 35 & $\begin{array}{c}\text { My Page - Courses - Exams - Library - Lists - Studies - Reports - } \\
\text { Groups - Portfolios - Files - Calendar }\end{array}$ & $.533-.805$ \\
\hline Factor 2 & 21 & $\begin{array}{c}\text { Professional Development - Content Production - Question and } \\
\text { Exam System }\end{array}$ & $.593-.848$ \\
\hline
\end{tabular}


As can be seen in Table 3, the load values of the articles in Factor 1 range from ,533 to .805, while the load values of the artiles in Factor 2 are between .593 and .848 . When the EBA modules to which the articles in the first factor are related are examined, this factor is called "Social Sharing Awareness" because all of them contain awareness about social skills such as sharing and interacting with students. Since the EBA modules to which the articles in the second factor are related include professional development, content production, and awareness of teachers' professional development by producing, such as creating questions and exams, this factor is also called "Professional Development and Production Awareness".

The most frequently used method for reliability calculation in Likert-type measurement tools is the calculation of Cronbach's Alpha coefficient (Büyüköztürk, 2018). The reliability calculation results of the Teacher EBA Awareness Scale are given in Table 4.

Table 4. Reliability results regarding the sub-dimensions of the teacher EBA awareness scale

\begin{tabular}{|l|c|c|}
\hline Factors & Number of Articles & $\begin{array}{c}\text { Cronbach's Alpha Internal } \\
\text { Consistency Coefficient ( } \alpha \text { ) }\end{array}$ \\
\hline Factor 1 - Social Sharing Awareness & 35 & .940 \\
\hline Factor 2 - Professional Development and Production Awareness & 21 & .937 \\
\hline Total & 56 & .946 \\
\hline
\end{tabular}

While determining the reliability of a measurement tool, it is generally considered sufficient if the calculated reliability coefficient is .70 or higher (Büyüköztürk, 2018). As can be seen in Table 4, the reliability of the measurement tool used in the research was calculated very high both in terms of sub-dimensions and total value.

While determining the participants of the research; announcements were made on digital communication platforms (forum sites, e-mail, social Media communities, communication applications) that teachers frequently are, and teachers were determined on voluntary hadis.

\section{Data Analysis}

The analysis of the data collected within the scope of the research was made using the IBM SPSS 22 statistical package program. The averages of the items under the two factors in the EBA Awareness Scale applied to the teachers participating in the research were taken and these scores were categorized. Tuncer (2005) formula was used to calculate the gap width while categorizing (4 ranges $/ 5$ options $=4 / 5=0.80$ ). The levels were found as follows by adding 0.79 to each range, taking into account the integer value.

1.00 - 1.79: Very Low Awareness

1.80 - 2.59: Low Awareness

2.60 - 3.39: Moderately Aware

3.40 - 4.19: High Awareness

4.20 - 5.00: Very High Awareness

It was accepted that the data showed a normal distribution as the (KMO) and Barlett sphericity tests, which were applied to determine the suitability of the data for factor analysis, were significant (Büyüköztürk, 2018). In this case, in order to determine the findings related to the research problems, descriptive statistics, Independent Samples T-Test for pairwise comparisons, and one-way ANOVA techniques for multiple comparisons were used. In the interpretation of the results, the level of significance was accepted as $\mathrm{p}=0.05$.

\section{FINDINGS}

\section{Findings Regarding EBA Awareness Levels of Teachers:}

The descriptive statistics regarding the EBA general awareness levels of teachers and the two factors of the Scale, Social Sharing Awareness and Professional Development and Production Awareness, are presented below.

Table 5.1. EBA awareness mean and standard deviation values of teachers

\begin{tabular}{|l|c|c|}
\hline \multicolumn{1}{|c|}{$\overline{\mathrm{X}}$} & $\mathrm{S}$ \\
\hline Social Sharing Awareness & 3,41 & 1,03 \\
\hline Professional Development and Production Awareness & 3,06 & 1,13 \\
\hline General Awareness & 3,24 & 1,02 \\
\hline
\end{tabular}

According to Table 5.1, the general awareness of the teachers participating in the research is "moderate" according to the EBA awareness mean and standard deviation values. While Social Sharing Awareness, which is the first of the two factors in the scale, was determined at "high" level, Professional Development and Production Awareness was found to be at "moderate" level.

Table 5.2. Distribution of teachers according to their EBA awareness levels 


\begin{tabular}{lccccccccccccc}
\hline & \multicolumn{2}{c}{ Very Low } & \multicolumn{2}{c}{ Low } & \multicolumn{2}{c}{ Medium } & \multicolumn{3}{c}{ High } & \multicolumn{2}{c}{ Very High } & \multirow{2}{*}{ TOTAL } \\
\hline & $\mathrm{N}$ & $\%$ & $\mathrm{~N}$ & $\%$ & $\mathrm{~N}$ & $\%$ & $\mathrm{~N}$ & $\%$ & $\mathrm{~N}$ & $\%$ & $\mathrm{~N}$ & $\%$ \\
\hline Social Sharing Awareness & 23 & 9,4 & 20 & 8,2 & 69 & 28,3 & 72 & 29,5 & 60 & 24,6 & 244 & 100 \\
Professional Development and Production Awareness & 36 & 14,8 & 42 & 17,2 & 76 & 31,1 & 47 & 19,3 & 43 & 17,6 & 244 & 100 \\
General Awareness & 26 & 10,7 & 29 & 11,9 & 78 & 32,0 & 66 & 27,0 & 45 & 18,4 & 244 & 100 \\
\hline
\end{tabular}

When Table 5.2 is examined; According to the general awareness of EBA, it was found that teachers were at medium level with 78 participants (31.1\%) and this was followed at high level with 66 participants (27\%), very high with 45 participants (18.4\%), low with 29 participants (11\%) and a very low level with 26 (10.7\%) participants. EBA Professional Development and Production Awareness of the teachers is in parallel with these statistics, while according to the Social Sharing Awareness, it is seen that the highest number of teachers is at a high level with 72 participants (29.5\%). This was followed accordingly by 69 participants (28.3\%) with a medium level, 60 participants with a very high level (24.6\%), 23 participants with a very low level (9.4\%), and 20 participants with a low level (8.2\%).

\section{Findings Regarding EBA Awareness of Teachers by Branch Variable:}

In order to determine whether the EBA awareness of teachers differs according to their branches, the descriptive statistics and the findings of the one-way ANOVA test applied are presented below.

Table 6.1. Descriptive statistics for the branch variable of EBA Awareness of Teachers

\begin{tabular}{|l|c|c|c|}
\hline & $\mathrm{N}$ & $\mathrm{X}$ & $\mathrm{SS}$ \\
\hline Classroom Teaching & 56 & 3,11 & 1,1 \\
& & & 0 \\
\hline Technology Branches & 35 & 3,77 &, 79 \\
\hline Verbal Branches & 38 & 3,17 & 1,0 \\
\hline Numerical Branches & & & 1 \\
\hline Language Branches & 35 & 3,24 &, 90 \\
\hline Branches Requiring Special Abilities & 28 & 3,46 &, 87 \\
\hline Developmental Branches & 22 & 3,25 & 1,0 \\
\hline Total & & & 7 \\
\hline
\end{tabular}

Table 6.2. ANOVA results regarding the branch variable of teacher EBA awareness

\begin{tabular}{|c|c|c|c|c|c|c|}
\hline Variance Source & Sum of Squares & SD & Squares Avarage & $\mathrm{F}$ & $\mathrm{P}$ & Significant difference \\
\hline $\begin{array}{l}\text { Between } \\
\text { groups }\end{array}$ & 21.847 & 6 & 3,641 & 3,769 & .001 & $\begin{array}{c}\text { Techn. B > Class T., Developmental B. Language B. } \\
\text { > Developmental B. }\end{array}$ \\
\hline In-group & 228,959 & 237 & ,966 & & & \\
\hline Total & 250,806 & 243 & & & & \\
\hline
\end{tabular}

In order to test whether there is a significant difference in the EBA awareness of 244 teachers working in different branches according to their branches, one-way analysis of variance was performed and it was observed that there was a significant difference between the average scores of the groups $(F(6-237)=3.769, p<0.05)$. Tukey test was applied to find out between which groups the differences between the branches were. Accordingly, the teachers in the Technology Branches $(\bar{X}=3.77)$ were found to have more EBA awareness than the primary school teachers $(\bar{X}=3.11)$ and the teachers in the developmental branches $(\bar{X}=$ $2.68)$, and the teachers in the language branches $(\bar{X}=3.46)$ than the teachers in the developmental branches $(\bar{X}=2.68)$. The effect size value of the dependent variable, which indicates the ratio of the variance explained by the independent variable, was found to be $\eta 2=.087$ and showed that the branch variable had a moderate effect on teacher EBA awareness (Büyüköztürk, 2018).

\section{Findings Regarding EBA Awareness of Teachers by School Type Variable:}

In order to determine whether teachers' EBA awareness differs according to the types of schools they work in, descriptive statistics and the findings of the one-way ANOVA test applied are presented below.

Table 7.1. Descriptive statistics of teachers' EBA Awareness regarding school type variable

\begin{tabular}{|l|c|c|c|}
\hline & $\mathrm{N}$ & $\overline{\mathrm{X}}$ & $\mathrm{SS}$ \\
\hline Primary and Preschool & 77 & 3,03 & 1,1 \\
& & & 0 \\
\hline Secondary School & 112 & 3,44 & .87 \\
\hline
\end{tabular}




\begin{tabular}{|l|c|c|c|}
\hline High School and Special Education & 55 & 3,11 & $\begin{array}{c}1,0 \\
8\end{array}$ \\
\hline Total & 244 & 3,23 & $\begin{array}{c}1,0 \\
1\end{array}$ \\
\hline
\end{tabular}

Table 7.2. ANOVA results of teachers' EBA awareness regarding to school type variable

\begin{tabular}{|l|c|c|c|c|c|c|}
\hline Variance Source & Sum of Squares & SD & Squares Average & F & P & Significant difference \\
\hline $\begin{array}{l}\text { Between } \\
\text { groups }\end{array}$ & 8,818 & 2 & 4,409 & 4,391 & .013 & Secondary > Primary and preschool \\
\hline $\begin{array}{l}\text { In-group } \\
\text { Total }\end{array}$ & 241,988 & 241 & 1,004 & & & \\
\hline
\end{tabular}

A one-way analysis of variance was performed to test whether there was a significant difference in the EBA awareness of 244 teachers participating in the study according to the type of school they worked in, and it was observed that there was a significant difference between the average scores of the groups $(F(2-241)=4.391, p<0.05$. Tukey test was applied in order to find out between which groups the differences are according to the type of school in eba awareness. According to this, it was seen that the teachers working in secondary schools $(\bar{X}=3.44)$ had more EBA awareness than the teachers working in primary and preschool schools $(\bar{X}=3.03)$. The effect size value, which indicates the ratio of the variance explained by the independent variable, was found to be $\eta 2=.035$ and showed that the school type variable had a moderate effect on teacher EBA awareness.

\section{Findings Regarding the Effect of Technological Tools on EBA Awareness:}

The results of the independent samples t-test applied to see the effect of the number of technological tools that teachers have on their EBA awareness are presented below.

Table 8. Teacher EB by the number of technological devices owned awareness $t$-Test Results

\begin{tabular}{|l|c|c|c|c|c|c|}
\hline Tool number & $\mathrm{N}$ & $\overline{\mathrm{X}}$ & $\mathrm{SS}$ & $\mathrm{sd}$ & $\mathrm{t}$ & $\mathrm{p}$ \\
\hline 1 or 2 & 151 & 3,11 &, 98 & 242 & $-2,52$ & .012 \\
\hline 3 or 4 & 93 & 3,44 & 1,03 & & & \\
\hline
\end{tabular}

According to the independent sample t-test results in Table 8 , it was observed that there was a statistically significant difference in the EBA awareness of teachers according to the number of technological tools they had $[t(242)=-2.52, p=.012]$. Accordingly, it can be said that teachers who have 3 or 4 technological tools $(\bar{X}=3.44)$ have more EBA awareness than teachers who have 1 or 2 tools $(\bar{X}=3.11)$. The effect size value of the dependent variable, which indicates the ratio of the variance explained by the independent variable, was found to be $\eta 2=.026$ and showed that the variable of the number of technology owned had a moderate effect on teacher EBA awareness.

\section{Findings on the Effect of Teachers' Technology Use Skills on EBA Awareness:}

One of the questions in the Personal Information Form, which is one of the data collection tools used within the scope of the study, is "What level do you think your technology use skills are?" consisting of two options as "Low" and "High". is the question.

The results of the independent samples t-test applied to see the effect of teachers' technology use skills on their EBA awareness are presented below.

Table 9. T-test results of teacher EBA awareness according to technology use skills

\begin{tabular}{|c|c|c|c|c|c|c|}
\hline & $\mathrm{N}$ & $\overline{\mathrm{X}}$ & $\mathrm{SS}$ & $\mathrm{sd}$ & $\mathrm{t}$ & $\mathrm{p}$ \\
\hline Low & 98 & 2,82 &, 96 & 242 & $-5,56$ & .000 \\
\hline High & 146 & 3,51 &, 95 & & & \\
\hline
\end{tabular}

According to the independent sample t-test results in Table 9, there was a statistically significant difference in teachers' EBA awareness according to their technology use skills $[\mathrm{t}(242)=-5.56, \mathrm{p}<.05]$. Accordingly, it can be said that teachers with high technology use skills $(\bar{X}=3.51)$ have more EBA awareness than teachers with low technology use skills $(\bar{X}=2.82)$. The effect size value of the dependent variable, which indicates the ratio of the variance explained by the independent variable, was found to be $\eta 2=.114$ and showed that the technology use skill variable had a moderate effect on teacher EBA awareness.

\section{Findings on the Relationship Between Having ITC Teachers in Schools and EBA Awareness of Teachers:}

The results of the independent samples t-test, which was applied to see the effect of the presence of ITC teachers in the schools where the teachers participating in the research, on their EBA awareness are presented below.

Table 10. T-test results showing the EBA awareness of teachers according to the presence of ITC Teachers in schools

\begin{tabular}{|l|c|c|c|c|c|c|}
\hline Is there ITC? & $\mathrm{N}$ & $\overline{\mathrm{X}}$ & $\mathrm{SS}$ & $\mathrm{sd}$ & $\mathrm{p}$ \\
\hline Yes & 147 & 3,26 &, 96 & 242 & .670 \\
\hline No & 97 & 3,20 & 1,08 & \\
\hline
\end{tabular}


According to the independent sample t-test results in Table 10, it was seen that there was no statistically significant difference in the EBA awareness of the teachers according to the presence of ITC teachers in the schools where they work $[\mathrm{t}(242)=0.427, \mathrm{p}$ $=.670]$.

\section{Findings on EBA Awareness of Teachers According to Their EBA Education Status:}

The results of the independent samples t-test applied to see the effect of the teachers' training on EBA on their EBA awareness are presented below.

Table 11. T-test results showing teachers' awareness according to their EBA education status

\begin{tabular}{|l|c|c|c|c|c|c|}
\hline EBA Training & $\mathrm{N}$ & $\bar{X}$ & $\mathrm{SS}$ & $\mathrm{sd}$ & $\mathrm{t}$ & $\mathrm{p}$ \\
\hline Having & 102 & 3,41 & .95 & 242 & 2,260 & .025 \\
\hline Not having & 142 & 3,11 & 1,04 & & & \\
\hline
\end{tabular}

According to the independent sample t-test results in Table 11; It was seen that there was a statistically significant difference in the EBA awareness of the teachers who received training on EBA $(\bar{X}=3.41)$ compared to those who did not receive EBA training $(\bar{X}=3.11)[t(242)=0.427, p=.670]$. The effect size value was found to be $\eta 2=.021$ and it showed that teachers' EBA training had a low level of effect on their EBA awareness.

\section{Findings Regarding the Effects of Teachers' Awareness of the Latest Updates in EBA on EBA Awareness:}

EBA was finalized, and was added on the basis of the date of this research. The distribution of the answers given by the teachers to this question is as follows:

\section{Do you know that Education Information Network (EBA) on 18 February 2020 is updated?}

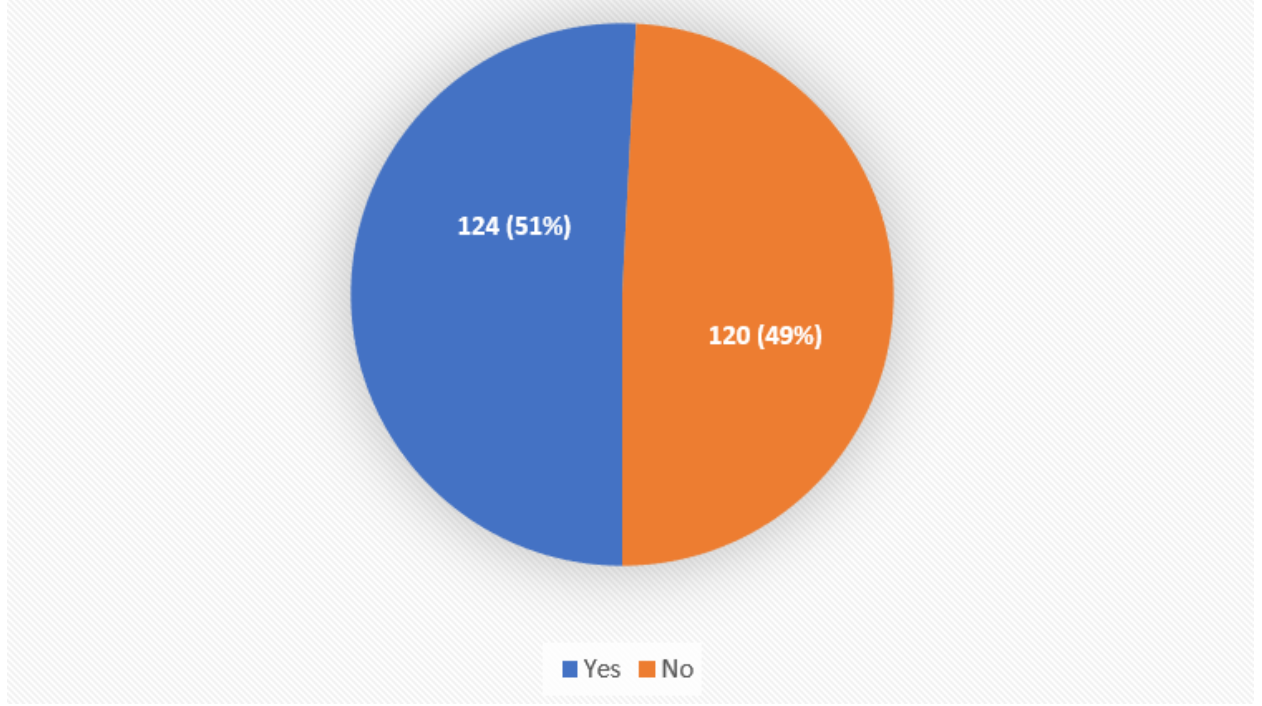

Figure 1. Distribution of teachers' awareness of the latest EBA update

In Figure 1, it is seen that $51 \%$ of the teachers are aware of the latest update in EBA, while $49 \%$ of them are unaware of this update. The results of the independent samples t-test applied to investigate the effect of this situation on EBA awareness are presented below:

Table 12. T-test results showing EBA awareness according to the situations of being informed of the EBA update

\begin{tabular}{|l|c|c|c|c|c|c|}
\hline Being Aware of The Updates & $\mathrm{N}$ & $\bar{X}$ & SS & sd & $\mathrm{t}$ & \multicolumn{1}{c}{. } \\
\hline Yes & 124 & 3,73 & .81 & 242 & 8,977 & \\
\hline No & 120 & 2,72 & .95 & & & \\
\hline
\end{tabular}

According to the independent sample t-test results in Table 12; It was seen that there was a statistically significant positive difference in EBA awareness of teachers $(\bar{X}=3.73)$ who were aware of the last update in EBA compared to those who were not aware of the update $(\bar{X}=2.72)[t(242)=8.977, p<.05]$. The effect size value was found to be $\eta 2=.250$ and it showed that teachers' awareness of the latest update in EBA has a very high effect on their awareness of EBA (Büyüköztürk, 2018).

Findings on Examining EBA Awareness of Teachers According to the Number of EBA Modules They Use: 
In order to determine whether teachers' EBA awareness differs according to the number of EBA modules they use, descriptive statistics and the findings of the one-way ANOVA test applied are presented below.

Table 13.1. Descriptive statistics on EBA awareness of teachers and the number of EBA Modules they use

\begin{tabular}{|l|c|c|c|}
\hline \multicolumn{1}{|c|}{$\mathrm{N}$} & $\overline{\mathrm{X}}$ & $\mathrm{SS}$ \\
\hline Never using & 24 & 2,10 & 1,10 \\
\hline Only one module & 38 & 2,75 &, 79 \\
\hline Only 2 modules & 40 & 2,81 & 1,01 \\
\hline Only 3 modules & 36 & 3,40 &, 90 \\
\hline Only 4 modules & 40 & 3,67 &, 87 \\
\hline Only 5 modules & 26 & 3,65 & 1,07 \\
\hline 6 modules and above & 40 & 3,93 &, 99 \\
\hline TOTAL & 244 & 3,23 & 1,01 \\
\hline
\end{tabular}

Table 13.2. ANOVA results regarding the correlation between teacher EBA awareness and number of modules they use

\begin{tabular}{|l|c|c|c|c|c|c|}
\hline Variance Source & Sum of Squares & SD & Squares Average & F & P & Significant difference \\
\hline $\begin{array}{l}\text { Between } \\
\text { groups }\end{array}$ & 79,592 & 6 & 13,265 & 18,36 & .000 & $\begin{array}{c}+6 \text { modules, only 5, only 4> none, only 1, } \\
\text { only 2, only 3> none, only 1 }\end{array}$ \\
\hline In-group & 171,215 & 23 & .722 & & \\
\hline Total & 250,806 & 24 & & & & \\
\hline
\end{tabular}

In order to test whether there is a significant difference in the number of modules used by the teachers in their EBA awareness, one-way analysis of variance was performed and it was observed that there was a significant difference between the average scores of the groups $(F(6-237)=18,362, p<0.05)$. The Games-Howell test was applied to find out between which groups the differences were. Accordingly, it is seen that EBA awareness of teachers using 6 modules or more $(\bar{X}=3.93)$, teachers using only 5 modules $(\bar{X}=3.65)$, and teachers using only 4 Modules $(\bar{X}=3.67)$ have found to be significantly higher than the EBA awareness of the teachers who have never used EBA $(\bar{X}=2.10)$, using only 1 module $(\bar{X}=2.75)$ and using only 2 modules $(\bar{X}=2.81)$. In addition, it was observed that teachers using only 3 Modules $(\bar{X}=3.40)$ had significantly more EBA awareness than teachers who never used $\operatorname{EBA}(\bar{X}=2.10)$ and only used 1 module $(\bar{X}=2.75)$. Effect size value, which indicates the ratio of the variance explained by the independent variable to the dependent variable was found as n2=317 and showed that the number of modules used had a very high effect on teacher EBA awareness.

\section{Findings on the Relationship Between EBA Usage Frequency and Awareness of Teachers:}

In order to determine whether the EBA awareness of teachers differs according to the frequency of EBA use, the descriptive statistics and the findings of the one-way ANOVA test applied are presented below.

Table 14.1. Descriptive statistics on teachers' EBA Awareness and EBA Usage Frequency

\begin{tabular}{|l|c|c|c|}
\hline & $\mathrm{N}$ & $\overline{\mathrm{X}}$ & $\mathrm{SS}$ \\
\hline None & 27 & 2,27 & 1,15 \\
\hline Several Times a Year & 38 & 2,76 &, 95 \\
\hline Several times in a term & 55 & 3,15 &, 84 \\
\hline A Few Times A Month & 47 & 3,52 &, 80 \\
\hline Several Times a Week & 62 & 3,60 &, 82 \\
\hline Every Day & 15 & 4,04 & 1,10 \\
\hline TOTAL & 244 & 3,23 & 1,01 \\
\hline
\end{tabular}

Table 14.2. ANOVA results regarding the frequency of EBA use of EBA awareness of teachers

\begin{tabular}{|l|c|c|c|c|c|c|}
\hline Variance Source & Sum of Squares & SD & Squares Avarage & $F$ & P & Significant difference \\
\hline $\begin{array}{l}\text { Between } \\
\text { groups }\end{array}$ & 55,718 & 5 & 11,144 & 13,595 & .000 & $\begin{array}{r}\text { Every Day> none, several times a year, } \\
\text { several times in a term, }\end{array}$ \\
\hline $\begin{array}{l}\text { In-group } \\
\text { Total }\end{array}$ & 195,088 & 238 &, 820 & & & $\begin{array}{r}\text { several times a week, several times a month> } \\
\text { no several times,year } \\
\text { several times aPeriod }>\text { no }\end{array}$ \\
\hline
\end{tabular}

In order to test whether there is a significant difference in the EBA awareness of the teachers according to the frequency of EBA use, one-way analysis of variance was performed and it was observed that there was a significant difference between the mean scores of the groups $(F(5-238)=13.595, p<0.05)$. Tukey test was applied to find out between which groups the differences were. Accordingly, teachers who use EBA every day are found to have significantly more EBA awareness than $(\bar{X}=4.04)$; teachers who never used $\operatorname{EBA}(\bar{X}=2.27)$, used it a few times a year $(\bar{X}=2.76)$, and used it a few times a term $(\bar{X}=3.15)$. In addition, the EBA 
awareness of teachers who used EBA a few times a week $(\bar{X}=3.60)$ and a few times a month $(\bar{X}=3.52)$, were found to be significantly higher than the teachers never used EBA $(\bar{X}=2.27)$ and a few times a year $(\bar{X}=2,76)$. Finally, it was found that the EBA awareness of teachers who used EBA a few times during the period $(\bar{X}=3.15)$ was significantly higher than those who never used EBA $(\bar{X}=2.27)$, and the effect size value indicating the ratio of the variance explained by the independent variable of the dependent variable was calculated as $\eta 2=222$ and seen that the frequency of EBA usage has a high effect on teacher awareness.

\section{Findings Regarding the Modules Used by Teachers with EBA Experience:}

The distribution of modules used by teachers with EBA experience participating in the research is presented below.

\section{Modules Used}

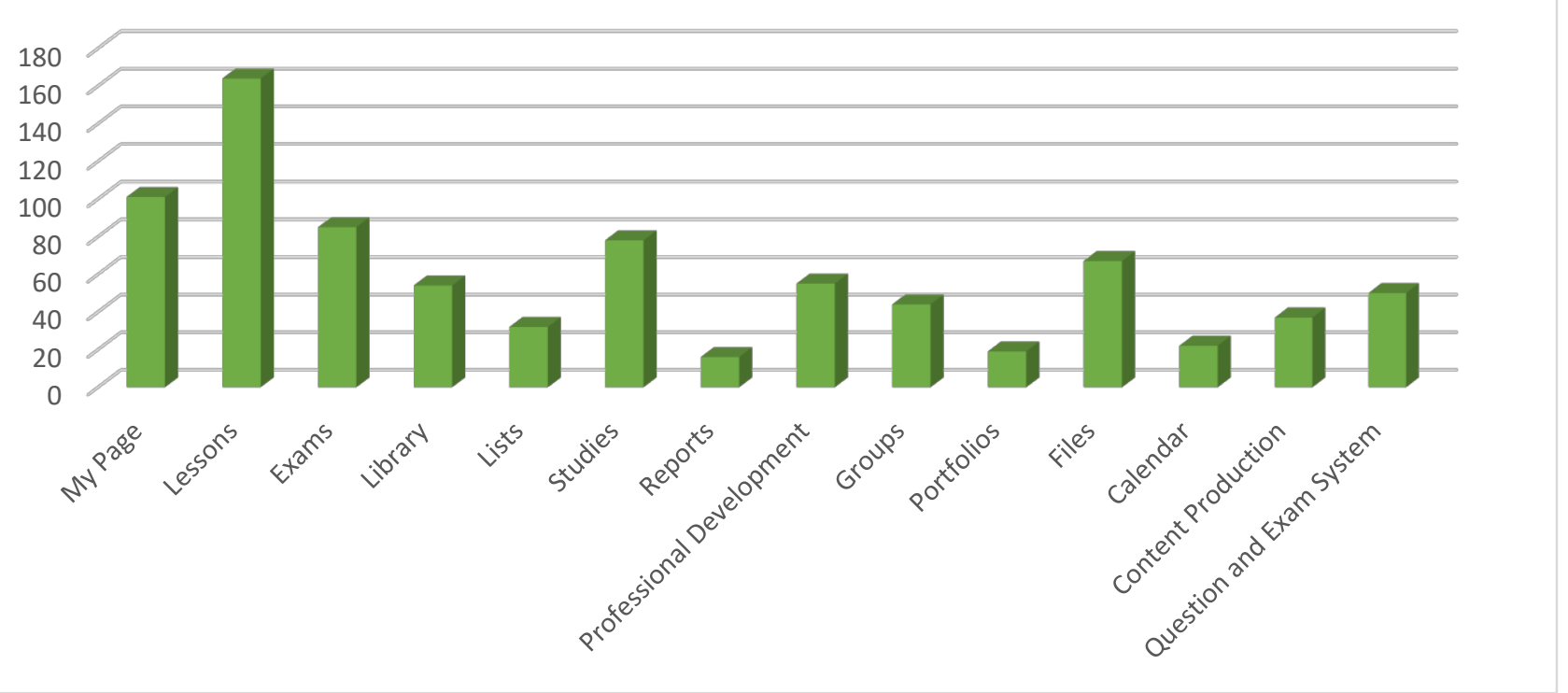

Figure 2. Usage distribution of EBA modules

As seen in Figure 2, the module most used by teachers in EBA is "Courses". It is seen that the two modules closest to this are the "My Page" and "Works" fields, respectively. The least used module is the "Reports" area. It is also noteworthy that the modules that make up the Social Sharing Awareness are used more than the Professional Development and Production Awareness modules. This situation shows parallelism with the awareness averages of the factors, which is the first finding of the study (see Table 4.1.).

\section{DISCUSSION, CONCLUSION AND RECOMMENDATIONS}

With this research, it was aimed to reveal the awareness levels of teachers about EBA and to examine them in terms of various variables, with an emphasis on "awareness", which is considered to have a significant effect on teachers' use of EBA. As a result of the descriptive analysis and comparisons made, teachers' awareness of EBA was found to be at "moderate" level and these awarenesses were found to show meaningful differences related to the branch, school type, number of technological tools owned, technology usage skills, education about EBA, being aware of the update made in EBA, EBA modules used and the frequency of EBA use but determined not to be affected from the variable of ITC teacher to be present at school.

The determination of teachers' EBA awareness as medium ( $\bar{X}=3.24)$ shows that these awarenesses are not yet at the desired and expected level. In a similar study, Sözcü and Karataş (2014) stated that teachers' awareness of the FATIH Project is weak. In other studies in the literature; Güvendi (2014) emphasizes that EBA is not introduced to teachers, Tutar (2015) suggests that teachers do not have knowledge about EBA, that it should be promoted and encouraged in schools, Alabay (2015) states that EBArelated training is needed and necessary promotions should be made to increase awareness about EBA. Kurtdede Fidan et al. (2016) say that teachers do not have enough knowledge about EBA, and Özgümüş (2018) state that EBA can be promoted through public service announcements or different broadcasting methods. The fact that even the teachers who are expected to guide students about the use of the EBA system do not have enough awareness about EBA reveals the necessity of implementing a new promotional model.

Considering the two sub-dimensions of the scale; It has been observed that the average of "Professional Development and Production Awareness", which includes Professional Development, Content Production and Question and Exam System modules, is lower and at "moderate" level compared to "Social Sharing Awareness". When the modules used by the teachers are examined, it is seen that the same modules are used less than the others. Aksoy (2017), Güvendi (2014) and Tutar (2015) stated that teachers 
use EBA in order to benefit from existing content rather than producing content, Karaçorlu and AIcI (2019) teachers do not use content production system, Kurtdede Fidan (2016) stated that they did not develop relevant content related to their own fields. Pekdemir Gerede (2019) concluded that the videos uploaded by the teachers in the EBA Content module are not suitable for multimedia criteria. According to Tanrıkulu (2017), although simple interface programs were added to EBA to prepare content, the purpose could not be achieved in terms of content. Ayan (2018), on the other hand, found in his thesis study that teachers do not sufficiently attend vocational courses in EBA. From all these, it can be deduced that teachers do not have enough awareness to participate in vocational courses and develop content-question-exams and that there is a need to take precautions in this context.

In the previous studies, Kuyubaşıoğlu and Kılıç (2019) found that the level of EBA use did not differ in terms of branch variable, contrary to this study, in their study that aimed to determine the level of EBA use of secondary school teachers and to examine them in terms of various variables. In a similar study, Alabay (2015) determined that there is a significant difference between branches in terms of usage level. In this study, when the EBA awareness on the basis of the branch variable was examined, it was seen that the teachers in the Technology Branches had more EBA awareness than the classroom teachers and the teachers in the developmental branches (Special Education - Guidance - Preschool), and the teachers in the language branches had more EBA awareness than the teachers in the developmental branches. It is thought that this situation is due to the difference in technological literacy levels among teachers. It is thought that the high technological literacy of technological branches such as information technology teachers, together with the training they receive before service, has a positive effect on EBA awareness. In addition, it can be evaluated that this situation arises from the fact that teachers in developmental branches give more importance to face-to-face interaction and concrete materials.

Considering the EBA awareness of the teachers according to the school type variable, it was seen that the teachers working in secondary schools had more EBA awareness than the teachers working in primary and pre-school schools. In a similar study, Güvendi (2014) concluded that primary and secondary school teachers use EBA more than high school teachers. The reasons for this situation can be examined with further research.

When the EBA awareness of teachers is examined according to the number of technological tools, which is another variable of the research; As the number of technological tools owned increases, it is seen that EBA awareness also increases. Whether the application of tablet distribution to some of the teachers with the FATIH project of the Ministry of National Education supports this situation may be the subject of research.

Considering the relationship between teachers' technology use skills and EBA awareness, it is seen that teachers with high technology use skills have more EBA awareness. In this context, it may be important to increase the technological literacy of teachers before or in-service to increase EBA awareness.

In the schools practicing this project which was started by the Ministry of National Education with the FATIH project, there are ITC teachers who were assigned by the provincial/district National Education Directorates. One of the main duties of these teachers is to introduce and inform the teachers and students in the school about the use of EBA (Tekirdağ il MEM, 2017). One of the results of this research is the finding that the presence of ITC teachers in schools does not have a significant effect on EBA awareness. In line with this finding, it can be suggested to review the effectiveness of teachers working as ICT in schools.

Many previous studies have revealed that: promotional and training activities significantly increase the rates of EBA usage (Alabay, 2015; Coşkunserçe and Becit İştürk, 2019; Güvendi, 2014; Kuyubaşığlu and Kılıç, 2019). In Aksoy (2017)'s research, teachers stated that adequate in-service training about EBA was not provided as the reason why other teachers could not use EBA competently. Becit İşçitürk and Turan (2018) stated that teachers' lack of training on EBA or that they do not find the training they receive sufficient affects their use of EBA negatively. EBA-related education status of teachers, which is thought to be an important variable in this study, positively affects their awareness of EBA. However, it is very thought-provoking that almost half of the teachers participating in the research $(\mathrm{N}=102)$ have not received any training on EBA. In this case, as stated in previous studies (Alabay, 2015; Karaçorlu \& Aıcl, 2019; Pekdemir Gerede, 2019), the number of in-service training for teachers on EBA can be increased and more teachers can use EBA. In addition, in line with the finding that was the subject of the previous discussion; presentations for other teachers by BTR teachers during the beginning and end of the year professional development programs of teachers, etc. By organizing activities, both the use of EBA and the effectiveness of BTR teachers can be increased.

Within the scope of the research, the teachers were asked whether they were aware of the revision on February 18, 2020, which was the last update of the EBA as of the date of implementation. It is noteworthy that $49 \%(N=120)$ of the teachers were not aware of this revision. Similarly, in the study of Saklan and Ünal (2019), the promotion of EBA was found insufficient. EBA Alabay (2015) found in his study that teachers who have knowledge about the FATIH project use EBA more than those who do not. In this study, the relational analysis showed a similar situation. Being aware of the updates had a high positive effect on teachers' EBA awareness.

When EBA awareness of teachers is examined according to the variables of the number of modules used and the frequency of EBA use, it can be said that the number of modules and their frequency of use have a positive effect on their EBA awareness. It can be said that teachers who use a large number of modules and teachers who use EBA more frequently have more EBA 
awareness. It would not be wrong to express this in reverse: As EBA awareness increases, teachers use EBA more frequently and more modules. If it is aimed to increase the use of this platform, teachers' awareness of EBA should be increased in line with this finding.

As a result, the findings obtained in this study revealed the following: Teachers' awareness of EBA is at "'moderate" level and these awarenesses are; It differs significantly according to the variables of branch, school type, number of technological tools owned, technology usage skills, EBA education, being aware of the update made in EBA, the number of EBA modules used and the frequency of EBA use, but is not significantly affected by the variable of the presence of ITC teachers in schools. In this regard, the following recommendations are made to the relevant authorities and researchers in the field:

- Since it is important to be aware of the platform when using EBA, taking measures to announce and share new applications and features published on the platform to teachers can increase awareness. In this sense, it can be suggested to use more effective methods for promotion.

- Providing technical support to teachers regarding EBA, especially during the entry process, can increase both awareness and level of use.

- The modules that teachers prefer less to use in EBA can be determined through the statistics in the system and measures can be taken for this.

- Considering the in-service training provided, courses focusing on "practice" can be organized to increase the use of EBA, as stated in previous studies.

- Various events (competitions, awards, etc.) can be organized to draw attention to the use of EBA.

- Considering that one of the findings obtained in the study is the low level of teacher use of content creation modules in EBA; a standard content preparation guide can be created for teachers. In addition, considering that the presence of an ITC teacher, which is another finding, does not have a significant effect on EBA awareness; It can be ensured that both the level of use of these modules and the effectiveness of ITC teachers can be increased with applied content production activities for other teachers by ITC teachers during the beginning and end of the year professional development programs of teachers.

- Considering both the effect of technology use skills on EBA awareness and the fact that content production modules are not used frequently by teachers, according to the study; A general awareness of technology usage can be created from the pre-service period by focusing more on the design, production and use of e-content in the instructional technologies and material design courses of the teachers during their undergraduate education.

- By making the "Technology Integration in Education" course compulsory in all faculties and departments that train teachers, it can be ensured that all teacher candidates are technology literate individuals and they are trained knowing how to integrate technological elements into education and training processes.

- Similarly, more reliable and valid studies can be conducted with a wider participant base and by considering different variables.

\section{Declaration of Conflicting Interests}

The authors declared no potential conflicts of interest with respect to the research, authorship, and/or publication of this article.

\section{Funding}

The authors received no financial support for the research, authorship, and publication of this article.

\section{Statements of publication ethics}

We hereby declare that the study has not unethical issues and that research and publication ethics have been observed carefully.

\section{Researchers' contribution rate}

The study was conducted and reported with equal collaboration of the researchers.

\section{Ethics Committee Approval Information}

Ethics Committee Approval for the research was obtained from Van Yüzüncü Yıl University Social and Human Sciences Ethics Committee with its official letter dated 09/06/2020 and numbered E.36805.

\section{REFERENCES}

Aksoy, N. (2017). EBA (Eğitim Bilişim Ağı)' nin kullanım amacı, karşılaşılan sorunlar ve çözüm önerileri. (Yüksek Lisans Tezi), Kahramanmaraş Sütçü İmam Üniversitesi, Kahramanmaraş. 
Alabay, A. (2015). Ortaöğretim öğretmenlerinin ve öğrencilerinin EBA(Eğitimde Bilişim Ağı) kullanımına ilişkin görüşleri üzerine bir araştırma. (Yüksek Lisans Tezi), İstanbul Aydın Üniversitesi, İstanbul.

Ayan, E. (2018). Öğretmenlerin eğitim bilişim ağı içeriğini kullanma ve e-içerik geliştirme durumlarının incelenmesi. (Yüksek Lisans Tezi), Hacettepe Üniversitesi, Ankara.

Aydınözü, D., Sözcü, U. ve Akbaş, V. (2016). Coğrafya öğretiminde eba içeriklerinin öğrenci başarısına etkisi. Karadeniz Sosyal Bilimler Dergisi, 8(15), 339-357.

Bahçeci, F. ve Burak, E. (2018). Öğrencilerin Eğitim Bilişim Ağı (EBA) Sitesine Yönelik Görüşlerinin Değerlendirilmesi. Kuramsal Eğitimbilim Dergisi, 11(4), 676-692.

Bayyiğit Teker, Ş. (2019). Öğretmenlerin teknolojik pedagojik alan bilgisi (TPAB) yeterlilikleri ile eğitim bilişim ağı (EBA) kullanımına yönelik tutumları arasındaki ilişki. (Yüksek Lisans Tezi), Balıkesir Üniversitesi, Balıkesir.

Becit İşçitürk, G. ve Turan, E. Z. (2018). Din kültürü ve ahlak bilgisi öğretmenlerinin eğitim bilişim ağı'na ilişkin görüşleri. Electronic Turkish Studies, 13(29).

Bertiz, Y. (2017). Çevrimiçi Sosyal Eğitim Platformlarının Kullanılabilirliklerinin Değerlendirilmesi: Eğitim Bilişim Ağı (EBA) Sistemi Örneği. Bilim Eğitim Sanat ve Teknoloji Dergisi, 1(2), 62-76.

Büyüköztürk, Ş. (2018). Sosyal bilimler için veri analizi el kitabı. Pegem Atıf İndeksi, 001-214.

Coşkunserçe, O. ve Becit İş̧itürk, G. (2019). Eğitim bilişim ağı (EBA) platformu hakkında öğrencilerin farkındalığının artırımasına yönelik bir durum çalışması. Journal of Qualitative Research in Education, 7(1), 1-17.

Dikmen, S. ve Bahçeci, F. (2020). Covid-19 Pandemisi Sürecinde Küresel Çapta Uygulanan Yükseköğretim Kurumlarındaki Uzaktan Eğitim Süreçleri Hakkında Durum Çalışması: Fırat Üniversitesi Örneği. Turkish Journal of Educational Studies, 7(2), 78-98.

Eğitim Bilişim Ağı (EBA). (2020a). Hakkında. https://www.eba.gov.tr/ adresinden 14 Mart 2020 tarihinde erişilmiştir.

Eğitim Bilişim Ağı (EBA). (2020b). Öğretmenlere Özel EBA Kullanım Simülasyonları. https://www.eba.gov.tr/kullanim-simulasyonlari adresinden 17 Mayıs 2020 tarihinde erişilmiştir.

Ekici, M., Arslan, İ. ve Tüzün, H. (2016). Eğitim Bilişim Ağı (EBA) web portalı kullanılabilirliğinin göz izleme yöntemiyle değerlendirilmesi. A. İ̧̧man, HF Odabaşı ve B. Akkoyunlu (Editörler) Eğitim teknolojileri okumaları, 273-296.

Elçiçek, A. (2019). Eğitim Bilişim Ağı (EBA) web sitesinin öğretmenler tarafından kullanım sıklığının incelenmesi Mardin ili Kızıltepe ilçesi örneği. (Yüksek Lisans Tezi), Sakarya Üniversitesi, Sakarya.

Erensayın, E. (2018). Çevrimiçi ders materyallerinin değerlendirilmesi: EBA ders örneği. (Yüksek Lisans Tezi), Van Yüzüncü Yıl Üniversitesi, Van.

Erensayın, E. ve Güler, Ç. (2017). EBA platformundaki ders materyallerinin eğitsel yazılım değerlendirme ölçütlerine göre değerlendirilmesi. Ahi Evran Üniversitesi Kırşehir Eğitim Fakültesi Dergisi, 18(1), 657-678.

Erensayın, E. ve Güler, Ç. (2019). Çevrimiçi Ders Materyallerinin Değerlendirilmesi: EBA Ders Örneği. Hacettepe Üniversitesi Eğitim Fakültesi Dergisi.

Ertem Akbaş, E. (2019). Eğitim Bilişim Ağı (EBA) Destekli Matematik Öğretiminin 5. Sınıf Kesir Konusunda Öğrenci Başarılarına Etkisi. Journal of Computer and Education Research, 7(13), 120-145.

Fryer, L. K. ve Bovee, H. N. (2016). Supporting students' motivation for e-learning: Teachers matter on and offline. The Internet and Higher Education, 30, 21-29.

Gökdaş, İ. ve Kayri, M. (2005). E-öğrenme ve Türkiye açisindan sorunlar, çözüm önerileri. Yüzüncü Yıl Üniversitesi Eğitim Fakültesi Dergisi, 2(2).

Güvendi, G. M. (2014). Millî Eğitim Bakanlı̆ı'nın öğretmenlere sunmuş olduğu çevrimiçi eğitim ve paylaşım sitelerinin öğretmenlerce kullanım sıklığının belirlenmesi: Eğitim Bilişim Ağı (EBA) örneği. (Yüksek Lisans Tezi), Sakarya Üniversitesi, Sakarya.

İşman, A. (2008). Uzaktan eğitim: Pegem Akademi.

Kalemkuş, F. (2016). Ortaöğretimdeki Öğretmen Ve Öğrencilerin Eğitim Bilişim Ağı (Eba)’Ya İlişkin Görüşleri. (Yüksek Lisans Tezi), Afyon Kocatepe Üniversitesi, Afyonkarahisar.

Kapıdere, M. ve Çetinkaya, H. N. (2017). Eğitim Bilişim Ağı (EBA) Mobil Uygulamasının Değerlendirilmesi. International Journal of Active Learning, 2(2), 1-14.

Karaçorlu, A. T. ve Atıcı, B. (2019). EBA Platformundaki Kavram Haritaları ve İnfografiklerin Kullanımına Dair Öğretmen ve Öğrenci Görüşleri. Gazi Eğitim Bilimleri Dergisi, 5, 77-96.

Kayaduman, H., Sırakaya, M. ve Seferoğlu, S. S. (2011). Eğitimde FATiH projesinin öğretmenlerin yeterlik durumları açısından incelenmesi XIII. Akademik Bilişim Konferansı Bildirileri (pp. 123-129). İnönü Üniversitesi, Malatya.

Kılıç Koçak, P. (2019). Milli Eğitim Bakanlığı Eğitim Bilişim Ağı'nda bulunan biyoloji dersi elektronik içeriklerinin değerlendirilmesi. (Yüksek Lisans Tezi), Hacettepe Üniversitesi, Ankara.

Kurtdede Fidan, N. (2016). Sınıf Öğretmenlerinin Eğitim Bilişim Ağı'ndan (Eba) Yararlanmaya İlişkin Görüşleri. Journal of International Social Research, 9(45), 626-626.

Kurtdede Fidan, N., Erbasan, Ö. ve Kolsuz, S. (2016). Sınıf Öğretmenlerinin Eğitim Bilişim Ağı'ndan (EBA) Yararlanmaya Illişkin Görüşleri. Journal of International Social Research, 9(45).

Kuyubaşığlu, R. M. ve Kılıç, F. (2019). Ortaokul öğretmenlerinin görüşlerine göre EBA (Ĕgitimde Bilişim Ağı) kullanım düzeylerinin incelenmesi. Journal of Advanced Education Studies, 1(1), 32-52.

| Kastamonu Education Journal, 2021, Vol. 29, No. 5 | 
Maden, S. ve Önal, A. (2018). Elektronik bilişim ağı (EBA)'ndaki ortaokul Türkçe dersi içeriklerinin kullanımı üzerine bir araştırma. Dil Eğitimi ve Araştırmaları Dergisi, 4(2), 101-121.

Milli Eğitim Bakanlığı (MEB). (2020a). Bakan Selçuk, Koronavirüs'e karşı eğitim alanında alınan tedbirleri açıkladı. http://www.meb.gov.tr/bakanselcuk-koronaviruse-karsi-egitim-alaninda-alinan-tedbirleri-acikladi/haber/20497/tr adresinden 15 Mayıs 2020 tarihinde erişilmiştir.

Milli Eğitim Bakanlı̆̆ı (MEB). (2020b). Eğitim Bilişim Ağı'nın (EBA) yeni dönem lansmanı gerçekleşti. https://yegitek.meb.gov.tr/www/egitimbilisim-aginin-eba-yeni-donem-lansmani-gerceklesti/icerik/2999 adresinden 20 Mart 2020 tarihinde erişilmiştir.

Milli Eğitim Bakanlı̆̆ (MEB). (2020c). Fatih Projesi Vizyonumuz-Misyonumuz. http://fatihprojesi.meb.gov.tr/about.html adresinden 20 Mart 2020 tarihinde erişilmiştir.

Milli Eğitim Bakanlığı (MEB). (2020d). Sayılarla Uzaktan Eğitim. https://yegitek.meb.gov.tr/www/sayilarla-uzaktan-egitim-23-mart-15-mayis2020/icerik/3047 adresinden 20 Mayıs 2020 tarihinde erişilmiştir.

Nakiboğlu, C. ve Gacanoğlu, Ş. (2019). Deneyimli Kimya Öğretmenlerinin Derslerinde Eğitim Bilişim Ağı (EBA) Ders İçeriklerini Kullanma Durumlarının İncelenmesi. Necatibey Eğitim Fakültesi Elektronik Fen ve Matematik Eğitimi Dergisi, 1141-1166.

Öz, H. (2016). Metacognitive Awareness and Academic Motivation: A Cross-Sectional Study in Teacher Education Context of Turkey. Procedia Social and Behavioral Sciences, 232, 109-121.

Özgümüş, Ö. (2018). Bursa ilinde öğrenci-veli-öğretmenlerin eğitim bilişim ağının kullanım sıklı̆ının belirlenmesi. (Yüksek Lisans Tezi), Bursa Uludağ Üniversitesi, Bursa.

Pekdemir Gerede, M. (2019). Eğitim Bilişim Ağı (Eba) 4.Sınıf Ders İçeriklerine Yönelik Videoların Çoklu Ortam Tasarım Ilkelerine Göre İncelenmesi. (Yüksek Lisans Tezi), Gazi Üniversitesi, Ankara.

Sağlık Bakanlığı. (2020). Türkiye'deki Koronavirüs Güncel Durumu. https://covid19.saglik.gov.tr/ adresinden 20 Mayıs 2020 tarihinde erişilmiştir.

Saklan, H. (2017). Bazi fen bilimleri öğretmenlerinin Eğitim Bilişim Ağı (EBA) hakkındaki görüşleri. (Yüksek Lisans Tezi), Gaziosmanpaşa Üniversitesi, Tokat.

Saklan, H. ve Ünal, C. (2018). Teknoloji dostu fen bilimleri öğretmenlerinin eğitim bilişim ağı (eba) hakkındaki görüşleri. Necatibey Eğitim Fakültesi Elektronik Fen ve Matematik Eğitimi Dergisi, 12(1), 493-526.

Saklan, H. ve Ünal, C. (2019). Dijital Eğitim Platformları Arasında EBA’nın Yeri ile İlgili Fen Bilimleri Öğretmenlerinin Görüşleri. Ondokuz Mayıs Üniversitesi Eğitim Fakültesi Dergisi, 38(1), 19-34.

Sözcü, Ö. F. ve Karataş, İ. H. (2014). Öğretmenlerin Fatih Projesine Illişkin Farkındalıkları ve Beklentileri: Bir Durum Analizi. Gaziantep University Journal of Social Sciences, 13(4).

Şahin, M. ve Erman, E. (2019). Tarih dersi öğretmenlerinin eğitim bilişim ağı'na (eba) ilişkin görüşlerinin incelenmesi. Mehmet Akif Ersoy Üniversitesi Eğitim Fakültesi Dergisi(49), 256-275.

Tanrıkulu, F. (2017). EBA’nın Türkçe dersi öğrenme alanlarını karşılama yeterliliğine yönelik öğretmen görüşleri. Ana Dili Eğitimi Dergisi, 5(3), 395416.

Tekirdağ il Milli Eğitim Müdürlüğü (MEM). (2017). Fatih Projesi Bilişim Teknolojileri Rehberliği Görevi. https://tekirdag.meb.gov.tr/meb_iys_dosyalar/2017_01/11165656_EK1_BTR_Gorevleri.pdf adresinden 8 Haziran 2020 tarihinde erişilmiştir.

Telli, S. G. ve Altun, D. (2020). Coronavirüs ve çevrimiçi (online) eğitimin önlenemeyen yükselişi. Üniversite Araştırmaları Dergisi, 3(1), 25-34.

Tuncer, M. (2005). Eğitimde ölçme ve değerlendirme. Ankara: Akış Yayınevi.

Tsai, Y.-h., Lin, C.-h., Hong, J.-c. ve Tai, K.-h. (2018). The effects of metacognition on online learning interest and continuance to learn with MOOCs. Computers \& Education, 121, 18-29. doi: https://doi.org/10.1016/i.compedu.2018.02.011

Tutar, M. (2015). Eğitim Bilişim Ağı (EBA) sitesine yönelik olarak öğretmenlerin görüşlerinin değerlendirilmesi. (Yüksek Lisans Tezi), Karadeniz Teknik Üniversitesi, Trabzon.

Türker, A. ve Güven, C. (2016). Lise öğretmenlerinin Eğitim Bilişim Ağı (EBA) projesinden yararlanma düzeyleri ve proje ile ilgili görüşleri. Eğitim ve Öğretim Araştırmaları Dergisi, 5(1), 244-254.

Tüysüz, C. ve Çümen, V. (2016). EBA ders web sitesine ilişkin ortaokul öğrencilerinin görüşleri. Uşak Üniversitesi Sosyal Bilimler Dergisi, 9(27/3), 278-296.

World Health Organization (WHO). (2020). Coronavirus. https://www.who.int/health-topics/coronavirus adresinden 15 Mart 2020 tarihinde erişilmiştir.

Yılmaz, B. A. (2013). Eğitimde FATiH Projesi ve Eğitim Bilişim Ağı (EBA). XV. Akademik Bilisim Konferansı Bildirileri (pp. 963-964). Akdeniz Üniversitesi, Antalya.

Yurdakul, B. (2016). Uzaktan eğitim. Pegem Atıf İndeksi, 2016(5), 271-288. 